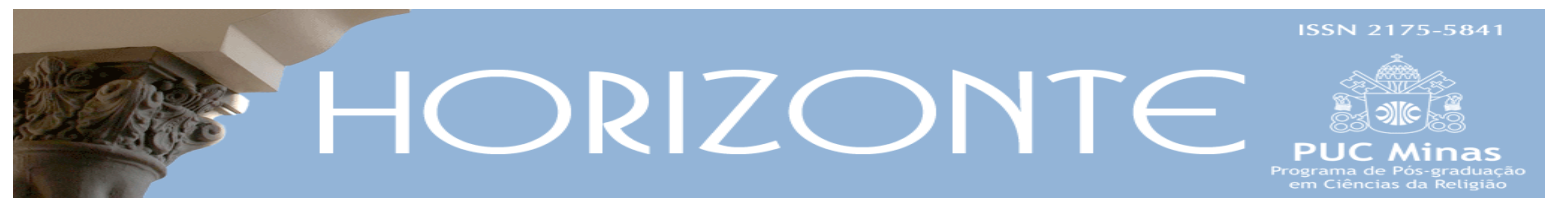

Dossiê: Espiritualidades, Filosofias e Religiões do Oriente - Artigo Original (0) 10 DOI - 10.5752/P.2175-5841.2016v14n43p765

\title{
O lugar da experiência \\ na práxis teológica das igrejas cristãs orientais
}

\author{
The place of experience \\ in theological praxis of the Eastern Christian churches
}

Paulo Augusto Tamanini *

\begin{abstract}
Resumo
Os conceitos, a linguagem e as acepções teóricas formulam um conhecimento. A Teologia, como área de um saber, também se serve de princípios teóricos para elucidar o Transcendente. Contudo, a Teologia Oriental apregoa que antes de todo conceito, os saberes decorrentes da experiência de fé do homem com Deus não são resultantes somente de fórmulas conceituais, axiomas irrefutáveis; brotam da intimidade pessoal e da experiência de fé que, longe de serem confundidas com ideologias, abstrações, alucinações de natureza psíquica, instituíam-se quais fundamentos e materialidade da teologia oriental. Neste universo de conhecimentos teológicos, afora o conjunto de conceitos, a fé oriental ultrapassa a lógica e parâmetros de um conhecimento elaborado apenas por teorias e dá espaço e relevância à experiência vivida. Para o cristianismo oriental, na experiência estão a chave, a distinção e a especificidade da Teologia oriental que procura dialogar com o mundo em sua inteireza. Este artigo discorre sobre o lugar da experiência na práxis teológica das igrejas cristãs orientais, buscando nos teólogos orientais ortodoxos gregos e eslavos os pressupostos e fundamentos para tal compreensão.
\end{abstract}

Palavras-Chave: Teologia Oriental; Experiência; Igrejas Cristãs Orientais; Práxis Teológica

\begin{abstract}
The concepts, language and theoretical meanings formulate knowledge. Theology, as an area of knowledge, also makes use of theoretical principles to elucidate the Transcendent. However, Eastern theology proclaims that before every concept, knowledge resulting from man's experience of faith with God are not only a result of conceptual formulas, irrefutable axioms; They stem from personal intimacy and the experience of faith that, far from being confused with ideologies, abstractions, psychic nature hallucinations, they showed themselves as the foundations and materiality of Eastern theology. Within this universe of theological knowledge, apart from the set of concepts, Eastern overcomes logic and the parameters of some knowledge made only by theories and gives space and relevance to lived experience. In Eastern Christianity, the experience is the key, distinction and specificity of Eastern theology that seeks to dialogue with the world in its entirety. This article discusses the place of experience in theological praxis of the Eastern Christian churches, seeking the Eastern Orthodox theologians Greeks and Slavs the foundation for such an understanding.
\end{abstract}

Keywords: Eastern theology; Experience; Eastern Christian Churches; Praxis Theological

\footnotetext{
Arttigo submetido em 23 de dezembro de 2015 e aprovado em 27 de setembro de 2016.

Agradeço à CAPES pela concessão da bolsa de PNPD.

* Doutor em História pela UFSC e mestre em História pela UDESC, especialista em Teologia Bizantina pela Escola Eclesiástica de Kilkis Grécia, licenciado em Filosofia pela UNIFEBE. Professor Bolsista PNPD-CAPES no Programa de Pós-Graduação em História da UFPR. País de Origem: Brasil. E-mail: tamanini@terra.com.br
}

Horizonte, Belo Horizonte, v. 14, n. 43, p. 765-788, jul./set. 2016 - ISSN 2175-5841 


\section{Introdução}

As problemáticas levantadas nas pesquisas de cunho religioso, em suas diversas possibilidades de recorte acerca de um objeto, tentam decodificar os saberes a partir de num lugar e marco epistemológico distintos. Logo, é dentro de uma contextualização geográfica e sócio cultural que os objetos ou fontes historiográficas sobre o Oriente e os assuntos correlatos a ele devem ser estudados, investigados, interpretados e compreendidos. Disso decorre que as temáticas relativas às religiosidades orientais, cristãs ou não, também são despertadas a partir de desdobramentos conceituais pensados em um lugar. Assim, o lugar tornase um ponto de construção de saberes que nem sempre estão em conformidades hermenêuticas com outros conhecimentos. A antropologia olhará para os indivíduos ou cultura do Oriente, respaldada em suas lógicas e métodos; de igual forma a Teologia e a Filosofia assim o fazem. Mesmo que haja compartilhamento ou comungação de fontes, cada uma dessas áreas de conhecimentos enxergará o Oriente buscando respostas às perguntas feitas, obedecendo critérios de legitimidade conceitual. Talvez, mais importante que achar as respostas é saber fazer as perguntas obedecendo aos princípios racionais acerca de uma realidade circunscrita.

Ao mesmo tempo, é preciso entender que os plurais saberes que caracterizam os diversos campos investigativos sobre as religiões e religiosidades orientais, em suas diversas denominações, (Cristianismo, Budismo, Hinduísmo, Bramanismo, Confucionismo, Xintoísmo, Taoísmo) tentam oferecer ao mundo uma compreensão a respeito do Transcendente que é capaz de revelar-se, mostrarse, relacionar-se com o humano. Tal apreensão acarreta efeitos práticos e decifratórios na elaboração de conceitos, de discursos, de promulgação de dogmáticas, conteúdos doutrinários e princípios teóricos que formam um corpo conceitual distinto que chamamos de Teologia. Afinal, o conhecimento metódico reivindicado pela Teologia não funciona sem definições, conceituações, pareceres; 
como ciência ela também precisa de uma maneira ajustada de pensar sobre seu objeto.

O cristianismo, como religião experimentada e posteriormente instituída portanto, formalizada e formatada por dizeres e lógicas - nasceu no Oriente. De lá, espraiou-se para diversas partes do Ocidente, levando consigo um modo de pensar e compreender Deus (SPIDLIK, 2002). O corpo dogmático e doutrinal aprovado no Oriente cristão pelos sete primeiros Concílios Ecumênicos, tornou-se a espinha dorsal da Teologia cristã que explanava e elucidava racionalmente as verdades instituídas sobre a fé em Jesus Cristo, o Logos encarnado, o Verbo prometido pelo Pai.

Os que iam de encontro ao estabelecido pela Igreja em matéria de fé ou se contrapusesse aos dogmas, eram acusados de caírem em cisma, porque alimentavam conceitos, arrazoados que justificavam a separação, a ruptura, a heresia. No entender da Teologia Oriental, a heresia é o erguimento ou a edificação de razões feitas por mediação das palavras, que explicam a escolha deliberada por uma parte da verdade, por um único aspecto da certeza, relativizando as outras partes e os outros aspectos. O processo dessa escolha é sempre intelectual, como consequência de uma preferência teórica que tenta esquematizar certa compreensão eclesial. A Igreja como jurisdição e respaldada por decisões conciliares, reagindo mediante o anúncio de verdades-parciais (heresias) tentava por limites, instituindo o dogma. Era o dogma que impedia que as certezas ou as verdades promulgadas pelos Concílios perdessem sua totalidade e catolicidade. Heresia e dogma, portanto, são resultantes de estruturas fundamentadas e justificadas por conceitos, por palavras, por pareceres.

Nesse sentido, as palavras são facilmente manipuladoras e manipuláveis porque, dependendo de quem as usa, embasa as defesas ou as contestações. Por isso, o Oriente cristão faz lembrar que antes de toda formulação dogmática, os saberes da Teologia eram decorrentes da relação do homem com Deus; não eram 
resultantes só de fórmulas conceituais, axiomas irrefutáveis; brotavam de uma experiência que, não podia ser confundida com ideologias, abstrações, alucinações de natureza psíquica (MESKIN, 1987).

Para as igrejas cristãs ortodoxas de vertente grega e eslava, por exemplo, na experiência estão a distinção e a chave para a compreensão da Teologia Oriental. Até porque, para o pensamento teológico ortodoxo, toda relação com a divindade fora da experiência mística com o próprio Deus torna-se abstrata, ideológica, individualizante e desencarnada (FELMY, 2002). Este artigo, portanto, trata da experiência como especificidade da Teologia oriental e chave de compreensão da práxis teológica das igrejas cristãs bizantinas gregas e eslavas.

\section{Teologia cristã oriental como resultante de conceitos, lugares e experiências.}

Oriente e Ocidente não foram assim chamados por acaso, até porque toda nomenclatura tem sua historicidade e fundamentos. Se foram nomeados, criados, inventados para designar as porções de espaço, na contemporaneidade se instituem para além disso, quais marcas e atributos de identidades, pensamentos e culturas. Não sendo o Oriente e o Ocidente blocos homogêneos dentro dos quais nem tudo se assemelha, é possível verificar que o Oriente, tido por Hegel como o "lugar onde começa a vida e aonde o sol nasce" (HELGEL, 1995, p. 194), nem sempre significou prosperidade, ascensão e luz. Sobretudo, na formulação da doutrina e dogmas cristãos, o Oriente foi palco de inúmeras contendas, batalhas axiológicas, sombras e dúvidas. $\mathrm{Na}$ contemporaneidade, na compreensão dos termos 'Oriente' e 'Ocidente' que extrapolam as marcos geográficos, verifica-se que os perímetros não mais obstaculizam a confluência de costumes, vivências, pensamentos e modos de se entender em um mundo cada vez mais globalizado, compartilhado e interligado pelos meios de comunicação. 
Por isso, quando as pesquisas se debruçam sobre temas acerca do Ocidente e do Oriente cuidam para não reduzir suas investigações a mera questão de antagonismos teóricos e abstratos, tampouco observar esses espaços quais pontos mapeados do globo (BRECK, 2013). Trata-se de diagnosticar que nestes extremos existe um modo diferente de compreender conceitos e teorias que se propõem a compartilhar. Os que agem de forma contrária são imediatamente taxados de fundamentalistas e remam contra a corrente da evolução cultural.

Decorrente disso, verifica-se que a distinção entre Oriente e Ocidente não é mais facilmente discernível, não é mais evidente, como no passado. O Ocidente e o Oriente não são mais apenas fronteiras geográficas; estão por toda parte e representam a simbiose e a materialidade de uma revolução cultural pondo em xeque a confluência de pressupostos teóricos concretos de ordem indenitárias demasiadamente exclusivistas (KNITTER, 2012).

No tocante às igrejas ou comunidades eclesiais orientais, torna-se imprescindível entender que, da mesma forma que se convencionou chamar de "Igreja Oriental” o conjunto de igrejas cristãs, nascidas em território não-ocidental - mas que nele se espalhou - os plurais saberes dogmáticos cristãos orientais que caracterizam diversas escolas teológicas, encontram-se catalogadas naquilo que se compreende por "Teologia Oriental”. Logo, quando dizemos "Igreja Oriental” ou “Teologia Oriental” queremos contemplar e se referir à multiforme realidade do conhecimento teológico cristão oriental que explica e legitima suas igrejas particulares. Como não há uma só igreja oriental não haverá também uma só teologia oriental (ANDRONIKOV, 1992).

Assim, em cada Igreja particular do mundo oriental, de procedência grega ou eslava, unida ou não entre si, o reconhecimento canônico e a legitimação se dão dentro de uma lógica e uma coerência respaldadas em pressupostos teológicos específicos. As comunidades cristãs orientais encontrarão em seus cânones as justificativas para aceitar ou rechaçar pareceres que possam contribuir ou 
ameaçar suas verdades. O mesmo fazem os ocidentais. Mesmo no Oriente, as vozes de tantos cristãos que se somam a tantas outras denominação e crenças plurais, interrogam as práticas de fé em uma hermenêutica circunscrita e relativa ao escopo de certa tradição e herança cultural. Isto posto, é compreensível que o pensar teológico oriental seja fortemente tributário de um passado distante e de um lugar geograficamente localizado de pouca familiaridade para nós, ocidentais.

No tocantes às religiões e religiosidades, ao se descrever sobre as teologias cristãs orientais sublinha-se que tal conhecimento ultrapassa a mera formalidade doutrinal, nem se trata de uma apresentação sistemática dos dogmas ou das verdades religiosas próprias do cristianismo oriental. Neste universo do conhecimento teológico, afora o conjunto de conceitos, a fé oriental excede à lógica e parâmetros de um conhecimento elaborado apenas por teorias e dá espaço e relevância à experiência vivida (YANNARAS, 1971).

A teologia oriental fundamenta que a experiência de fé acerca de Deus leva também a conhecê-lo de um modo específico (apofático) e que foge da pura racionalidade. O Oriente, não obstante, observa que o costume de pensar de maneira formal e legalista sobre tudo cria o hábito de objetivar as realidades e de substituir a indeterminação dinâmica da vida por esquemas e modelos prontos. Se o moralismo e o totalitarismo encontram seu arrazoado na forma de conhecimento positivo, logo, a verdade pode ser manipulada pela lógica, bastando apenas traçar os axiomas corretos. As certezas tornam-se escravas do inteligir humano, dos princípios e das leis, relegando outras formas de se conhecer a verdade ao puro subjetivismo e à mera especulação.

A teologia oriental se recusa a esgotar o conhecimento sobre Deus pela via racional, conceitual, doutrinal, baseando-se também na empiria, na experienciabilidade que está além de toda formulação lógica. Nesse sentido, o corpo teórico é posterior à experiência e à relação pessoal com Deus, credenciando 
linguagem urdida pela experiência, pela contemplação, pelo estupor, pelo maravilhamento (que brota das celebrações litúrgicas e da veneração aos ícones, por exemplo) como elocução científica plausível. Geradora de saberes, a experiência equipara-se então, à linguagem esquematizada e convencional proveniente do polido raciocínio e das noções menos descuradas, para compor o quadro teórico da teologia que ordena as Igrejas cristãs de vertente grega e eslavas.

Longe das grandes cátedras universitárias e dos grandes polos de pesquisas, também as orações, os cantos litúrgicos, o olhar, o silêncio, o perfume do incenso, o tremular das velas acesas, o constante persignar da pessoa frente à sacralidade instituem-se acepção e compreensão da encarnação do Logos que se manifesta no humano. Nesse entendimento, os ensaios gestual e introspectivo, as celebrações monacais, os rituais vespertinos e os ofícios litúrgicos densos levam a um conhecimento sobre as realidades sagradas que a razão apenas complementa. Esse modo de compreender as formulações teológicas acerca de Deus faz com que, diante do maravilhamento oriundo da experiência, os conceitos se tornem apenas suporte; a inteligibilidade perde sua função exclusiva para o perfeito entendimento; e o arrazoado deixa de ter a última palavra (LOSSKY, 1967).

Na Teologia cristã oriental, se entende que diante do ícone, por exemplo, a relação espiritual com o divino do homem e da mulher inteiros têm preponderante participação. Porque o que se contempla no ícone é a individualidade do Logos encarnado escrita em cores e formas e não os sentimentos ou formosuras humanas. No ícone, os símbolos remetem àquilo que Deus se deixou revelar, nem sempre decifráveis pelo intelecto. Desde modo, não só a razão tenta chegar a um conhecimento acerca do divino, mas a pessoa como realidade inteira (com seus sentidos, emoções, experiência) contribui para esse fim. É a pessoa em sua totalidade hipostaseada de corpo e alma que conhece e experimenta o divino no humano. 
No entanto, Ioannis Zizioulas, teólogo oriental grego, adverte que até mesmo a experiência mística vivida em uma profunda intensidade, é incapaz de conhecer Deus em sua totalidade. Porque "somente o que se pode conhecer acerca de Deus é o que foi dado pela Revelação, sendo Ele muito mais que isso". Identificar a Deus pelo o que demonstra a Criação e a Encarnação do Verbo não faz jus a sua ontologia (ZIZIOULAS, 2011). Ainda assim, a experiência mística dá sua contribuição à Teologia porque enfatiza a incapacidade humana de somente positiva e racionalmente, se conhecer quem é Deus em sua inteireza.

\section{O Oriente e o Ocidente e a clivagem entre o Império e a Igreja: a substituição da experiência pela razão}

Para além de rubricas falsamente unificadoras, tanto no Oriente quanto no Ocidente cristãos, luz e trevas coexistiram (ZIZIOULAS, 2003, p. 101). A morte, o sangue, os conluios, os conchavos ou alianças e as disputas de poder, as traquinagens e as vilanias foram encenadas em ambos os lugares. Neles as experiências da dor e do afastamento de Deus também encontram seus regaços; e, por vezes, em ambientes em que a reluzente coroa régia tinha chancela e fazia eco com as das altas ou arredondadas mitras episcopais.

Tanto a Teologia como a História, como áreas de conhecimento em conexão, demonstra que nos três primeiros séculos de cristianismo, na Igreja não havia forte ou incontestável formulação de princípios teóricos a respeito das verdades e dogmas que anunciava. A pequena e recente comunidade cristã vivia da imediatez do anúncio da Boa Nova, sem elaborações sentenciosas. Era a fase da vivência experimental de uma fé gestada na crença de um Deus encarnado. Ainda que fosse um período embrionário, o testemunho da certeza vivida e experimentada não prescindia de um convencimento pessoal, capaz de justificar a determinação de, até mesmo, entregar sua vida por causa daquela nova crença. Essa razão, essa certeza, ou persuasão não vinha de pressupostos teóricos, mas da experiência e 
proximidade de um Deus que se fazia humano. Uma fé que tinha sua gênese na escuta do Evangelho, no entendimento das epístolas, na leitura das cartas e missivas que os primeiros bispos compunham para dirigir e orientar as primeiras comunidades. Aquela fé não era uma certeza ideológica, sustentada por argumentos; era um movimento de confiança em que se depositava as expectativas e sede de vida nova em Deus, promovida pela experiência pessoal (LOSSKY, 1976).

Ainda que pese a fase rudimentar institucional da Igreja cristã, em que a experiência era a mediação de conhecimento, no decorrer do primeiro milênio, com a realização dos Concílios, consolidou-se o escriturístico, as normativas, a letra. Por isso, o segundo e revolucionário estágio de estabelecimento da Igreja é marcado pelo Edito de Milão, decretado pelo imperador Flavius Valerius Aurelius Constantinus ou Constantino I (272-337), no ano de 313, quando a fé cristã passava a ser tolerada nos territórios do império romano. O reinado de Constantino tornouse uma linha divisória na história da Igreja cristã: de figura de proa e monarca pagão passou a governante aureolado pela sacralidade das insígnias cristãs (SAID, 2007).

O fato de o Império Romano do Ocidente ter capitulado diante da invasão dos Alanos, Vândalos e Suevos, na segunda metade do século V, Constantino encontrou em Bizâncio ${ }^{1}$ o lugar estratégico para dar continuidade ao império, formando aliança com o bispo local, na época Metrophanes. Se com o Edito de Milão (313) decretado por Constantino, o cristianismo era apenas tolerado no império romano, foi o imperador Teodósio (com o Edito de Tessalônica, em 360) que avançou e consolidou o cristianismo não apenas em religião tolerada, mas exclusiva e oficial dentro da circunscrição territorial do império romano (GIORDANI, 1992, p. 87).

\footnotetext{
${ }^{1}$ Fundada pelos imigrantes gregos em 637 a.C., Bizâncio, colônia helênica localizada entre os mares Negro e Egeu, tornou-se oficialmente a capital do império romano no Oriente, em 395, por decreto do imperador Teodósio que, antes de morrer dividiu-o territorialmente para seus filhos Arcádio e Honório. Para sinalizar o período novo no império, ordenou que modificassem o nome da capital Bizâncio para Constantinopla, já que o antigo nome remetia ao deus grego Byza. (RIVEROS; HERRERA CAJAS. 1998, p.15).
} 
A igreja que vivia anteriormente da experiência e do testemunho, passava a partir dali a alicerçar suas certezas também na razão, teoremas, conceitos, formulações dogmáticas. Com o abraço do Império, a igreja cristã deixava de ser excluída para ser recepcionada pela corte e dela ganhar o status, indumentária, signos e aparatos régios, conservados até o momento presente nas Igrejas cristãs Orientais católicas e ortodoxas, ainda que sob justificativas de novos critérios e hermenêuticas teológicas. Se de um lado, a incorporação de insígnias próprias da simbologia e do poder imperial, presentes nos ritos e cerimônias religiosas desenhavam e organizavam os modos de ser de uma igreja que se servia do poderio para se legitimar, de outro, o império apropriava-se do capital simbólico e do conjunto de dispositivos imagéticos e materiais de poder (divino) para legitimar e justificar muitos de seus mandos.

O cristianismo desde então guardou duas faces de uma mesma realidade institucional (a latina e a bizantina) que se viu apartada no século XI, quando do Cisma de 1054. A separação do cristianismo em comunhão fez instituir duas igrejas (a ortodoxa, no Oriente e a católica, no Ocidente) que não mais se reconheciam partes integrantes de um mesmo corpo eclesiástico. Tal desconhecimento voluntário e intencional diagnosticou o surgimento de um fosso teológico que ainda na contemporaneidade se tenta ajustar.

Contudo, o desvincelhamento entre Oriente e Ocidente cristãos possibilitou que cada porção desenvolvesse teologias específicas: enquanto a do Oriente primava pela mística e experiência, capazes de fundamentar conceitos, a do Ocidente reafirmava a primazia das palavras e da razão para explicar a Deus. Tais diferenças geraram consequências organizacionais, administrativas, compreensões eclesiológicas distintas e, muitas vezes, antagônicas e excludentes. Enquanto a eclesiologia ocidental baseada na primazia, por exemplo, admitia a existência de uma só igreja, a sinodalidade oriental e a valorização da experiência eclesial de cada lugar e cultura contribuíram para o surgimento de várias igrejas particulares que, juntas e em comunhão, formavam um corpo jurídico canônico pluriforme. 
Observa-se outra vez que a experiência ditou as normativas para que uma nova comunidade eclesial ou Igreja tivesse sua canonicidade reconhecida.

Atualmente, as igrejas cristãs orientais estão assim agrupadas: 1) Igreja Assiríaca do Oriente ou Igreja Nestoriana; 2) Igrejas Ortodoxas Monofisistas nãocalcedônias (Igreja Armênia, Igreja Copta, Igreja Etíope, Igreja Siríaca e Igreja Malankar); 3) Igrejas Ortodoxas Orientais (Constantinopla Alexandria, Antioquia, Jerusalém, Rússia, Romênia, Grécia, Sérvia, Bulgária Geórgia, Chipre, Polônia, Albânia, Checo-Eslováquia e América); Igrejas Ortodoxas Autônomas (Monte Sinai, Finlândia, Japão e China) 4) Igrejas Canônicas dependentes de Constantinopla (Igreja Ortodoxa Carpático-russa, Igreja Ucraniana da América e do Canadá; Igreja Russa na Europa Ocidental; Igreja Albanesa da América; Igreja Bielorusso na América do Norte.

Ainda há um grupo que preserva, como os ortodoxos, os mesmo ritos, tradição, calendários litúrgicos e organização interna, mas são ligadas à Igreja de Roma: Igreja Maronita, Igreja Ítalo-albanesa, Caldeana, Malabar, Armênia, Copta, Etíope, Siríaca, Malankar, Melquita, Ucraniana, Rutena.²

Dessas igrejas orientais - e carregando às costas o peso e as consequências de polarizações, fundamentalismos e dicotomias -, algumas chegaram ao Brasil, a partir do século XVIII, agrupadas conforme suas etnias e organizadas conforme a estruturação de eparquias diocesanas. O grupo de cristãos orientais de vertente ortodoxa, por exemplo, se organizou com o erguimento de suas distintas sedes administrativas eparquiais: a Ucraniana (Patriarcado Ecumênico) em Curitiba-PR; a Antioquina (Patriarcado de Antioquia) em São Paulo-SP; a Polonesa (Patriarcado da Polônia) no Rio de Janeiro, RJ; o Exarcado Patriarcal e Arquidiocese Grega (Patriarcado Ecumênico) em São Paulo-SP; as Arquidioceses da Rússia (Patriarcado de Moscou) no Rio de Janeiro-RJ, e da Sérvia (Patriarcado da Sérvia) em Recife-PE. O grupo de cristãos orientais católicos, por sua vez, se estruturou de

\footnotetext{
${ }^{2}$ Para uma melhor compreensão acerca da natureza, história, especificidade e teologia das igrejas cristãs orientais citadas ver: BINNS, 2009; KHATLAB, 1997; e GONZÁLEZ MONTESA, 2000.
} 
modo equivalente: a Eparquia Ucraniana Católica de Rito Oriental, em CuritibaPR; a Eparquia Maronita Católica de Rito Oriental, a Eparquia Melquita Católica de Rito Oriental e a Eparquia Armênia Católica de Rito Oriental, todas em São PauloSP.

Nessas cidades de acolhida, ainda hoje, as igrejas cristãs orientais continuam a pontificar um saber e um percurso de códigos que foram advindos de uma regularidade. O caldo de devoção religiosa - moldado pelas mediações simbólicas que circundam o lugar em que os orientais aportaram e ainda vivem - indica um fiel cristão oriental que tenta experimentar Deus à sua maneira, conforme seus costumes, crenças e tradições.

Por vezes, redesenhadas na tela dos espaços de acolhida, a face e a identificação étnico-religiosa dos herdeiros desse inventário cultural oriental passaram a ganhar novos tons e um colorido que traduz uma liberdade de escolha e de profissão de fé e pertencimento religioso. Contudo, longe de ser uma descontinuidade, os cristãos orientais ortodoxos e católicos, a um modo condizente ao contexto do espaço em que se sociabilizam, por vezes, trocam suas experiências, sem maiores revezes, com os cristãos latinos. Se de um lado, o lugar de acolhimento de cristãos orientais tentava ditar seu ritmo e impor a readequação cultural daqueles que nele procuraram aconchego, por outro, nesses espaços os ortodoxos e católicos orientais deixaram também suas marcas, sabendo com maestria conciliar a herança cultural com as novidades trazidas pelo urbano, mapeando relações com a alteridade. Com isso, a cultura religiosa cristã de vertente oriental no Brasil ainda pulsa, ganha carne e anuncia um modo de crer e relacionar-se com Deus legitimado pelo tempo, pela tradição e suas teologias. 


\section{Liturgias orientais: momentos da experiência e da práxis teológica}

As experiências e práticas devocionais têm um endereço; geralmente localizadas em um espaço que institui uma geografia mística, em que se opera uma passagem de tempo, onde o racional e a experiência misturam-se: o interior das igrejas. No templo, considerado casa de Deus, possibilita-se abertura para que os indivíduos assimilem algo de fé pelo conjunto que o circunda (STANILOAE, 1986).

Segundo Pàvel Evdokìmov, para se tentar compreender o mundo religioso oriental e suas práticas devocionais é preciso entrar nos meandros de sua Teologia (EVDOKÌMOV, 1990). Na atual concepção teológica cristã oriental, guiar a vida de fé de uma comunidade pela experiência religiosa tornou-se a principal missão da Teologia. Disso decorre que a manifestação da religiosidade dos cristãos orientais, em geral possibilita compreender, a partir de amostragens sensíveis e de práticas ritualísticas individuais ou coletivas, sua visão de mundo. A este respeito, o teólogo russo, naturalizado francês Jean Meyendorff, considera que por meio da liturgia, os cristãos orientais se reconhecem e experimentam a pertença a uma comunidade que nela se identificam. Para ele, a liturgia, então, é considerada como fonte e expressão não só de uma teologia de uma Igreja institucionalizada, como também, é a instância de onde brota a identidade e a continuidade da igreja-comunidade

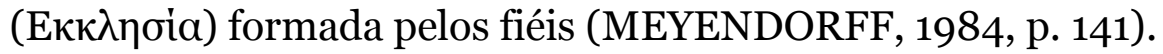

Por isso, na Carta Encíclica Orientale Dignitas, o Papa Leão XIII (18781903), insistia que os padres latinos, para que pudessem entender a identidade a que se reveste toda a Igreja (em suas porções oriental e ocidental), deveriam ter um conhecimento maior sobre a riqueza teológica e espiritual das diversas tradições teológicas, litúrgicas e espirituais do Oriente cristão (BRUNINI, 1997). O insistente 
pedido, reforçado nos pontificados posteriores e chancelado no Concílio Vaticano II, ganhou voz e materialidade expressa em gestos concretos de aproximação também dos pontífices João Paulo II, Bento XVI e Francisco.

Consoante a estes três últimos papas, o termo 'unidade' entre as porções oriental e ocidental da Igreja ganhou visibilidade e peso de um caminho irreversível quando assinaram respectivamente documentos oficiais com os expoentes das Igrejas Orientais Ortodoxas: Atenágoras I, Demétrios I e Bartolomeu I.

Afora os conceitos teológicos ou as assinaturas de acordos de cooperação institucional ou o propósito de não se medir esforços para a desejada unidade entre as igrejas, o conhecimento acerca de Deus se dá pelas celebrações litúrgicas. Contudo, as Igrejas Orientais católicas e ortodoxas ainda não podem concelebrar juntas muitos de seus ofícios religiosos, sobretudo a Divina Liturgia (na tradição oriental) ou a Santa Missa (na tradição ocidental) pela falta de plena comunhão entre as instituições. Por enquanto, por encontrarem-se em comunhão parcial, algumas celebrações litúrgicas lhes são permitidas. O padrão básico dos ofícios religiosos orientais é similar ao da Igreja Católica Romana, no Ocidente. Secundariamente, sobressaem as que são realizados diariamente: Ofícios de Matinas, Vésperas, Primeira, Tércia, Sexta, Nona e Completas. O ofício de Matinas é equivalente ao das Laudes no Rito Romano. E por fim, os Ofícios Sacramentais e de Bênçãos: Batismo, Casamento, Recepção Monástica, Coroação Real, Consagração de uma Igreja, Sepultamento dos mortos, bênção de casas, das águas, de crianças recém-nascidas, da mãe parturiente, Bênção dos Enfermos, de automóveis. Em cada uma dessas celebrações constitui-se um momento de encontro e de intimidade com Deus, que convida à introspecção e à recepção do mistério. 
Uma forte característica das celebrações orientais reside no fato de as orações serem cantadas em reto tom, com poucas alternâncias. A espiritualidade encontrou na inexistência da variação de tons e semitons dos hinos litúrgicos os caminhos para se instalar. Nas comunidades cristãs orientais, o canto não é acompanhado por qualquer instrumento; a voz humana impera sozinha e se alterna com a do celebrante. A voz da criatura em busca da experiência com seu Criador é soberana. Nem mesmo o som dos sinos pode afugentar a oportunidade do encontro. Por isso, os sinos se alojam fora da Igreja ou anexa a ela, em cima de torres. Isto porque, se entende que nada pode ofuscar a atenção do fiel que está ali para aprender a conhecer sagrado em suas formas rituais.

Como mostra a imagem abaixo, os templos das igrejas cristãs orientais são em geral cruciformes, com um largo espaço central coberto por uma cúpula, onde geralmente está iconografado a imagem do Cristo Pantocrator. As naves alongadas, comum nas catedrais e grandes igrejas paroquiais do estilo gótico ocidental não são encontradas na arquitetura de Igrejas Orientais. Segundo Zizioulas, o templo cristão oriental é assim configurado por ser o espaço da experienciabilidade, do encontro com o Inefável; é o lugar da aprendizagem sobre as realidades divinas pela via da contemplação e abstração. É a escola da razão que se faz fé (ZIZIOULAS, 2011). Para tanto, o espaço é projetado para que a experiência de fé encontra o cenário apropriado para uma gestação, onde as palavras se emudecem a razão cede sua primazia ao maravilhamento.

O pequeno nartex prepara a entrada do fiel para a grande nave; lá o fiel faz as primeiras reverências e orações. A oração, na concepção teológica oriental, é a força motriz de toda a vida espiritual, de todos os esforços humanos. É a conversação com Deus, é a relação pessoal com Deus, é a união com Deus, é a bússola do coração das virtudes (KATERELOS, 2014). A proximidade e intimidade com o divino faz da oração algo contínuo, encarnado porque já não é mais a pessoa quem reza, mas o próprio espírito divino que a faz. 
Figura 1: Infográfico do interior de um templo cristão Oriental (católico ou ortodoxo)

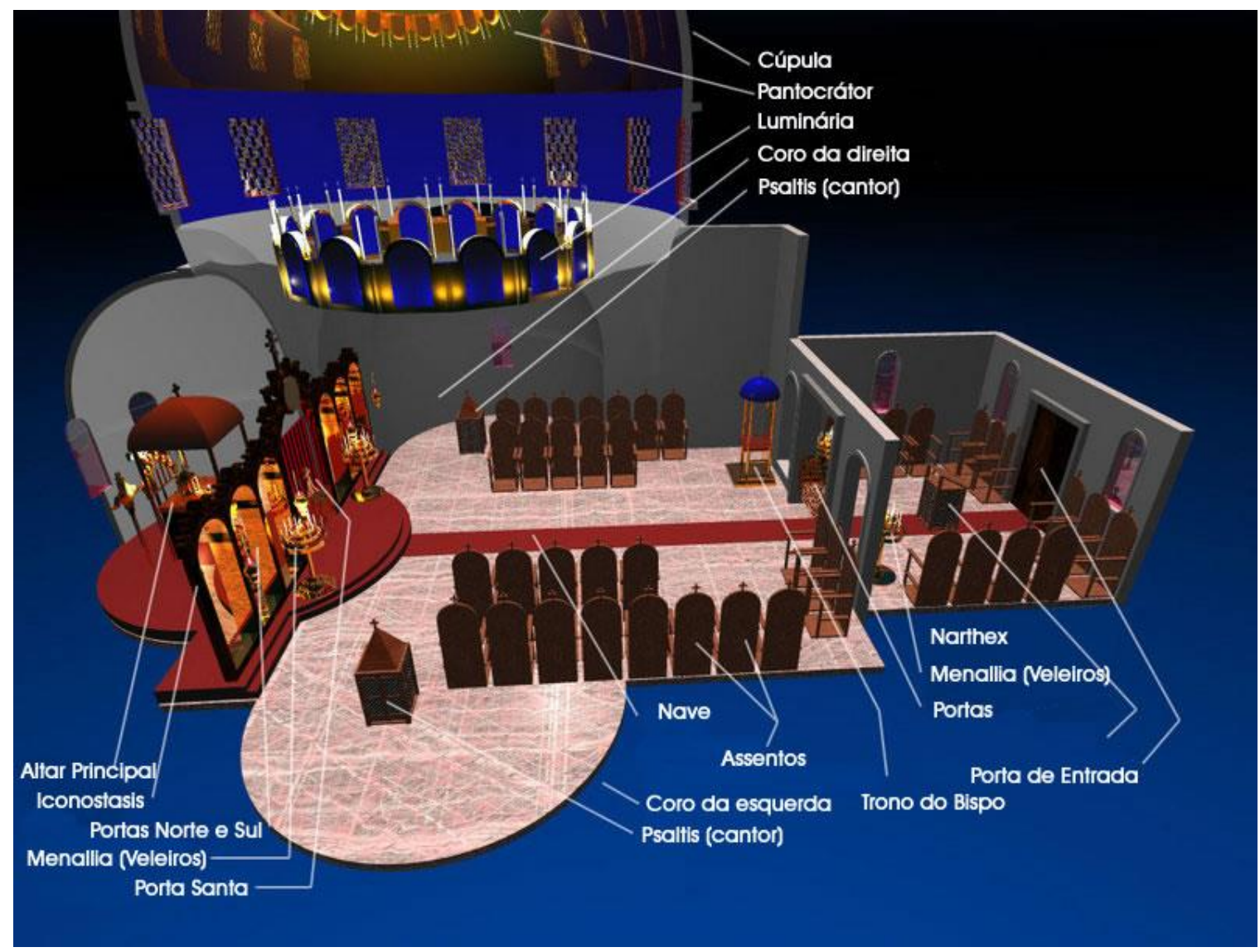

TAMANINI, 2013, p. 216.

Ao se entrar em uma igreja de estilo oriental, o fiel ou o visitante ingressa nesse ambiente iniciador de novas experiências e das novas teofanias. Não é somente o lugar em que o fiel faz suas primeiras orações e acende suas velas para o santo de devoção, mas é o ambiente das perdas. No nartex, perde-se ou deixa-se as perturbações humanas, para entregar-se à gratuidade. Outra característica de um templo cristão oriental é que na nave (onde ficam os fiéis) não se dispõem cadeiras ou bancos; as poucas cadeiras com encostos altos e arredondados estão dispostas juntas às paredes. Isto porque as igrejas orientais são construções pensadas para a vida monástica. Na perspectiva teológica monacal, os lugares dos monges são as laterais dos templos, porque o centro é ocupado pelo Cristo. Por isso, o cristão 
oriental, seguindo a regra monasterial, normalmente, fica de pé durante as celebrações; costume este pouco observado principalmente nos países de diáspora, como o Brasil. Algumas igrejas ucranianas e russas ortodoxas, no Sul brasileiro, ainda ressalvam esta prática.

Como mostra a imagem, em toda Igreja cristã oriental o altar principal é separado da nave por uma parede repleta de ícones, chamada de iconostásio. O iconostásio nas igrejas orientais anuncia a existência de uma passagem entre dois territórios, entre dois espaços instituídos, entre dois mundos que guardam seus sentidos e símbolos. Ultrapassando qualquer planejamento cênico e indo além de um gosto estético apurado, o iconostásio qual a cortina de um teatro deixa invisível o que guarda. Embora o conjunto iconográfico obedeça a uma disposição, regras, formas, tamanhos e conteúdo, não esconde uma ruptura, um confrontamento, uma linha que separa o sagrado e o profano, ao mesmo tempo em que possibilita a poucos (ou seja, aos hierarcas) o trânsito entre duas realidades. Se o rito solenemente glorifica e acentua a existência desses dois mundos, o iconostásio em cada igreja oriental é a materialidade dessa distinção.

Mircea Eliade, ao analisar especificamente as relações entre o sagrado e o profano, tenta demonstrar que, também a porta, ao menos num templo, não é tão somente uma passagem física, posto que está totalmente imbuída de sentidos outros. Em suas palavras:

A porta que se abre para o interior da igreja significa, de fato, uma solução de continuidade. O limiar que separa os dois espaços indica ao mesmo tempo a distância entre os dois modos de ser, profano e religioso. O limiar é ao mesmo tempo o limite, a baliza, a fronteira que distinguem e opõem dois mundos - e o lugar paradoxal onde esses dois mundos se comunicam, onde se pode efetuar a passagem do mundo profano para 0 mundo sagrado (ELIADE, 1992, p. 15).

Um exemplo dessa fronteira, desse limiar no sentido proposto por Mircea Eliade, pode ser as figuras que compõem a ornamentação o iconostásio, essa passagem entre os dois mundos. Em qualquer igreja oriental de estilo bizantino, o 
fiel diante da majestática parede, à esquerda contemplará o ícone de Maria Santíssima e à direita o de Jesus Cristo reproduzindo as posições de ambos em determinadas passagens bíblicas: Maria está de pé à esquerda contemplando o seu filho crucificado; e Jesus, como relata o credo apostólico, após subir ao céu, está sentado à direita de Deus Pai. A disposição de ambos no compósito do iconostásio, no passado tinha função de instruir os iletrados acerca dos mistérios da fé, hoje, deixa evidente que o que estava por trás daquela parede eivada de ícones é algo velado e mais santo que aqueles que se deixam ver. Se o iconostásio em sua fulguração tem como função primária instruir e catequizar, não escapa, contudo, de uma associação com a arte cênica podendo também abrir brechas por onde se insinuem mudanças, por onde se imponham novidades.

Os santos iconografados no iconostásio se por um lado abrem alas para o místico, por outro trazem o germe de uma inquietação, essa geradora fértil de conhecimento e de experiência com o divino (SPITERIS, 2003). Estar atrás de uma linha sem se preocupar com o que existe do outro lado parece não ser possível para as pessoas do mundo contemporâneo. A curiosidade, a investigação, a agudeza e a perspicácia em saber descobrir tornam qualquer indivíduo alguém inconformado. Os cristãos orientais de tradição bizantina, em seu modo de conceber suas crenças, parecem precisar da parede, da linha, do sinal que marca e separa. De todo modo, o iconostásio presente nos templos, seguindo em sua feitura um padrão fiel ao mundo bizantino, não deixa de incomodar, inquietar e motivar os fiéis a transpor as fronteiras e perceber que aquela parede - apartada de sua função primeira institui-se sinal material do mistério que só se deixa revelar pela experiência. Um veículo para um devir que, necessariamente, não precisa trazer respostas, mas que, certamente, proporciona ao fiel cristão uma maior possibilidade de proximidade com o Velado. 


\section{Conclusão}

Nas Igrejas Orientais o lugar da experiência de Deus está no espaço em que se celebra da liturgia. Por isso, ZiZioulas (2011), Eliade (1989) e Yannaras (1989) certificam que os templos não são lugares comuns; se sobressaem dos outros pela função que ocupam e porque representam o inefável. Sendo Deus aquele que é inexprimível, homens e mulheres usam de sua condição humana, das mediações e das ferramentas de acesso para dele se estar próximos: cantos, orações, gestos, silêncios; meditação, leituras, contemplação.

Sendo a fé cristã oriental essencialmente trinitária, a liturgia bizantina está carregada de símbolos que fazem referências ao Deus Pai, Filho e Espírito Santo. Tal assertiva é demonstrada, por exemplo, no grande número de persignações feitas pelos fieis desde sua entrada em um templo cristão oriental. Se os simples gestos condensam tal certeza, acreditam os teólogos gregos, que homens e mulheres podem experienciar o que esse Deus Uno e Trino deixa-se conhecer. Nesse sentido, todo ritual litúrgico e celebrativo prepara e capacita o fiel para a experiência de se compreender ou conhecer Deus através dos sentidos. Até porque, no convencimento cristão oriental a iniciativa da Revelação parte sempre do divino e não das vontades, da razão e dos caprichos humanos (FLOROVSKY, 1976). Na perspectiva latina tomista, no entanto, a razão humana inicia e torna-se a mola propulsora que principia um caminho de busca da verdade; é a razão que faz nascer reflexões dando o primeiro passo. Em uma época de tempos líquidos e entrecruzados, a Teologia cristã muito se enriqueceria se a mútua compreensão entre acadêmicos orientais e ocidentais fosse buscada, sem se preocupar com defesas prévias de suas verdades e a imposição de seus códigos de saberes. Tanto uma quanto outra tem suas estruturas conceituais bem formadas, inexoravelmente justificadas e defendidas. 
Ser cristão oriental não significa mais estar alijado do mundo ocidental. Ele sofre também as influências da secularização e do relativismo de valores favorecendo crises de identidades de instituições e credibilidade de valores. Nesse caldo turbulento de culturas novas, as igrejas orientais católicas ou ortodoxas se veem constantemente desafiadas em sua missão de dar respostas às perguntas nascidas do inconformismo dos jovens cristãos orientais. Vários grupos de fieis incitam que as instituições orientais também reflitam e deliberem sobre a maneira satisfatória de realizar no mundo contemporâneo, não só a ortodoxia de uma fé confessional, como também a ortopraxis do Evangelho de Jesus Cristo que nasceu na pequena Belém, na Judéia (BRUNINI, 1997).

Por isso, o conhecimento acerca do divino, para a Teologia oriental, não se deixa adquirir somente pela abstração, pela ciência, domínio e empregabilidade de conceitos e, tão pouco, mutilando-se ou anulando-se o tempo de espera e de paciência. E os lugares apropriados para o exercício dessa parcimônia gestadora de saberes são os espaços de oração, de meditação e de encontro com o divino. As igrejas cristãs orientais de vertente bizantina ou eslava apregoam, por isso, que a vida contemplativa é a escolha precisa para quem busca experimentar o Logos em sua singularidade. Ademais, para se experienciar o Verbo Encarnado, fundamenta a Teologia Oriental, não depende exclusivamente da vontade humana, do ato de querer, mas de uma iniciativa alheia a sua (LOSSKY, 1967). Desse modo, a vontade e a razão são colocadas em um segundo plano, tendo a graça ou o "dom que vem do alto" como norteadores de um saber; ainda assim, o conhecimento acerca de Deus é sempre tangenciado e nunca apreendido de forma absoluta ou total. Segundo a teologia oriental, o que podem ser captadas são apenas algumas energias incriadas ${ }^{3}$, reveladoras da Trindade de um Deus que é Uno agindo no mundo e no homem, imagem e semelhança do Logos. Energias essas que se ramificam e estão diluídas nas mais variadas formas de vida racional ou não.

\footnotetext{
${ }^{3}$ Energias incriadas é um verbete de Gregório Palamás que alude a um modo como a graça de Deus se manifesta no mundo. (PACOMIO; MANCUSO, 2003).
} 
A reflexão acerca de Deus é possibilitada também pelas energias brotadas das palavras que podem ser ouvidas ou pelas palavras que se emudecem no instante da contemplação. Daí porque a introspecção, esse momento de proximidade com o divino, dá-se pelo olhar, pelo silêncio, pelo emudecimento. Por isso, os ícones presentes nos iconostásios das Igrejas cristãs Orientais não são apenas a materialidade de um dom artístico, ou peças de uma decorada parede que apenas divide a nave do altar de um templo, mas se instituem veículos transmissores da mística capaz de gerar proximidade e identificação com o Logos. Nesse tipo de experimento, acreditam os grandes místicos cristãos orientais, a racionalidade dos dogmas e os conservadorismos de formas prontas das diversas teologias tendem a se curvar ante à simplicidade do apenas observar e adorar o mistério.

Embora o corpo teórico, conceitual, dogmático dos Concílios, esses instituidores e promulgadores de verdades, sejam também fruto de contendas, de escolhas feitas, de consensos, de exclusões e de acordos encenados e costurados desde os primeiros séculos, a História registra um caminho percorrido de formulações dessa fé também pela via da experiência. Disso decorre que, não só a razão burilou a crença cristã na formulação de propostos dogmáticos, como também a mística, a espiritualidade, o exercício de práticas litúrgicas e a introspecção deram seu contributo. Contudo, é bom frisar que para a Teologia oriental, a experiência mística e relacional com Deus não exclui os dogmas, os preceitos, o corpus canônico da Igreja, porque eles são percebidos como a racionalização do mistério, já experimentado por aquele que crê.

Talvez, atualmente, o grande desafio do cristianismo oriental não seja mais formular dogmas, mas a de traduzi-los em vida e conhecimento, onde o compromisso com Deus e o estar no mundo exerçam sua precedência, antes de qualquer disputa teológica. Como no início do cristianismo, a teologia oriental fundamenta que a experienciabilidade institui-se como a via de redescoberta do divino no humano, do aprofundamento espiritual e da introspecção ativa que leva à 
atividade de intelecção da alma em busca do Deus Uno e Trino que continua a fazer do homem e da mulher sua imagem e semelhança.

\section{REFERÊNCIAS}

ANDRONIKOV, Constantin. Dogma e mistica nella tradizione ortodossa. Bologna: Edizioni Dehoniane, 1992.

BINNS, John. Las iglesias cristianas ortodoxas. Madid: Ediciones Akal, 2009.

BRECK, John. L'écriture dans la tradition. Paris: Cerf, 2013.

BRUNINI, Marcello. La preghiera del cuore nella spiritualità dell'oriente Cristiano. Padova: Edizioni Messaggero, 1997.

CAPPELLETTI, Lorenzo. Primado ou hegemonia. Primado de uma separação. In.: Revista 30 Dias na Igreja e no Mundo, Roma, v. 22, n. 01, 2004.

ELIADE, Mircea. O mito do eterno Retorno. Lisboa: Edições 70, 1989.

ELIADE, Mircea. O sagrado e o profano: a essência das religiões. São Paulo: Martins Fontes, 1992.

EVDOKÌMOV, Pàvel Nikolàjevic. La conoscenza di Dio secondo la tradizione orientale. Roma: Edizioni Paoline, 1983.

EVDOKÌMOV, Pàvel Nikolàjevic. Teologia della bellezza. L'arte dell'icona. Roma: Edizioni Paoline, 1990.

FELMY, Karl Crhistian. Teología ortodoxa actual. Salamanca: Ediciones Sígueme, 2002.

FLOROVSKY, George . Creation and redemption. Belmont, Massachusetts: Nordland Publishing Company, 1976.

GEFAELL, Pablo. Cristiani orientali e pastorali latini. Milano: Giuffrè Editore, 2012.

GIORDANI, Mario C. História do Império Bizantino. Petrópolis: Vozes, 1992.

GONZÁLEZ MONTESA, Adolfo. Las iglesias orientales. Madrid: Ediciones cristianas, 2000.

HEGEL, G. W. F. A razão na história: introdução à filosofia da história universal. Lisboa: Edições 70, 1995. 
KHATLAB, Roberto. As igrejas orientais católicas e ortodoxas. Tradições vivas. São Paulo: Ave Maria, 1997.

KATERELOS, Kyrillos. L'apport de Nicolas Cabasilas à l'ecclésiologie à partir de la théologie des mystères . Strasbourg,Université de Strasbourg , 2014

KNITTER, Paul F. Introduzione alle Teologie delle Religioni. Roma: Queriniana, 2012.

YANNARAS, Christós. De l'absence et de l'inconnaissance de Dieu. Paris: Edition du Cerf, 1971.

YANNARAS, Christós. La vie de l'église. Paris: Edition du CERF, 1989.

LOSSKY, V. L'Image et la Ressemblance de Dieu. Paris: Aubier-Montaigne, 1967.

LOSSKY, V. The Mystical Theology of the Eastern Church. N. Iorque: St. Vladimir's Seminary Press, 1976.

MEYENDORFF, J. La teologia bizantina. Marietti, Casale Monteferrato, 1984.

MESKIN, Matta el. In.: DOTTI, Guido. Comunione nell'amore. Edizioni Qiqajon, Comunità di Bose, Magnano, 1987.

PACOMIO, Luciano; MANCUSO, Vito. Dicionário Teológico Enciclopédico. São Paulo: Loyola, 2003, p.562.

RIVEROS, J. M.; HERRERA CAJAS, H. El Império Bizantino: introducción histórica y selección de documentos. Chile: Facultad de Filosofía y Humanidades, 1998.

SABATELLI, Michael. A divina liturgia em rito bizantino eslavo. São Paulo: Edições Salesianas, 1995 .

SAID, Edward W. Orientalismo: o Oriente como invenção do Ocidente. São Paulo: Cia. das Letras, 2007.

SPIDLÍK, Tomás. La preghiera secondo la tradizione dell'Oriente Cristiano.

Roma: Lipa, 2002.

SPITERIS, Yannis. La teología ortodossa neogreca. Bolonia: Centro editoriale Dehonianio, 2003.

STANILOAE, Dumitru. Spiritualitate și comuniune în Liturghia ortodoxă, Craiova, 1986.

TAMANINI, P. A. A prece ucraniana na pressa da cidade: as renegociações das práticas religiosas ucranianas nos espaços da cidade de Curitiba a partir de 1960. 2013. 415 p. Tese (Doutorado) - Universidade Federal de Santa Catarina, Centro de Filosofia e Ciências Humanas, Programa de Pós-Graduação em História, Florianópolis. 
ZIZIOULAS, Ioannes. L'Eglise et ses institutions. Paris: Cerf, 2011.

ZIZIOULAS, Ioannis. El ser eclesial. Persona, comunión, Iglesia. Salamanca: Ediciones Sígueme, 2003. 